\title{
ARSITEKTUR SEBAGAI SARANA PENGEMBANGAN PENDIDIKAN KECERDASAN ANAK
}

\author{
Nathania Shareen Rimbani ${ }^{11}$, Franky Liauw ${ }^{2)}$ \\ 1)Program Studi S1 Arsitektur, Fakultas Teknik, Universitas Tarumanagara, nathshareein@gmail.com \\ 2) Program Studi S1 Arsitektur, Fakultas Teknik, Universitas Tarumanagara, frankyl@ft.untar.ac.id
}

\begin{abstract}
Abstrak
Kehidupan manusia di dunia tidak bisa terlepas dari lingkungannya yang terus berkembang seiring berkembangnya teknologi. Pendidikan menjadi salah satu cara dalam meningkatkan kualitas sumber daya yang mampu beradaptasi dan berkompetisi dibutuhkan untuk dapat bertahan hidup dalam perkembangan lingkungan di dunia. Tujuan pendidikan nasional jelas menyampaikan bahwa pendidikan dilakukan untuk meningkatkan kecerdasan rakyatnya baik itu kecerdasan intelektual (IQ), kecerdasan emosional (EI) dan kecerdasan spiritual (SI). Namun dalam praktiknya, institusi pendidikan lebih mengarah pada peningkatan IQ, melupakan EI dan SI yang sebenarnya tidak bisa terlepaskan satu dengan yang lainnya. Perubahan akibat digitalisasi dalam konsep pendidikan ini memunculkan suatu permasalahan dasar secara spasial yaitu perubahan tipologi sekolah atau ruang kegiatan sebagai lingkungan belajar. Bentuk arsitektur pendidikan anak yang dapat mengakomodasi kebutuhan emosional dan akademis anak berdasarkan kecerdasannya menjadi permasalahan desain utama. Sekolah Pukka Cisauk merupakan fasilitas pendidikan untuk anak sekolah dasar dan sekolah menengah pertama dalam mendukung peningkatan kecerdasan pada anak demi kualitas kehidupan yang lebih baik. Sistem pendidikan yang digunakan adalah pembelajaran berbasis proyek (PBL) dengan proses pembelajaran menitikberatkan pada siswa. Perbedaan identitas setiap individu diakomodasi dalam pembentukan ruang berdasarkan 8 kecerdasan majemuk yang diintegrasikan dengan prinsip belajar kolaboratif, kreatif, partisipatif, pengalaman, multiliterasi, personalisasi, menyenangkan dan interdisiplin dalam mencapai tujuan membentuk anak yang produktif, afektif dan kreatif.
\end{abstract}

Kata kunci: Kecerdasan; Pendidikan; Pembelajaran berbasis proyek (PBL)

\begin{abstract}
Human life cannot be separated from their environment which continues to develop along with technologies. Education is one of ways to improve the quality of human resources for adapting and competing for survival in this evolving world. The purpose of education is carried out to improve the intelligence of each people as intellectual intelligence (IQ), emotional intelligence (EI) and spiritual intelligence (SI). Educational institutions I practice are more directed at increasing IQ and tend to ignore El and SI. The changes due to digitalization in the concept of education raise a basic problem spatially, such as changes in school typology or activity space as a learning environment that can accommodate children's emotional and academic needs based on their intelligence. Pukka Cisauk School is an educational facility for elementary and junior high school children to support children's intelligence improvement for a better quality of life. The education system used is ProjectBased Learning (PBL) with a student-centered learning process. The different identities of each individual are accommodated in the formation of spaces based on 8 multiple intelligences which are integrated with the learning principles: collaborative, creative, participative, experiential, multiliteracies, personalized, playful and interdisciplinary in achieving to form productive, affective and creative children.
\end{abstract}

\section{Keywords: Education; Intelligence; Project-Based Learning (PBL)}




\section{PENDAHULUAN}

\section{Latar Belakang}

Kehidupan manusia di dunia tidak bisa terlepas dari lingkungannya termasuk dari berkembangnya teknologi. Hal tersebut dikarenakan dunia telah memasuki era revolusi industri 4.0 yang menurut Schwab (2016) ditandai dengan digitalisasi dari berbagai bidang yaitu meningkatnya konektivitas, interaksi serta berkembangnya sistem digital. Perkembangan teknologi informasi dan komunikasi telah banyak mengubah cara pandang dan gaya hidup manusia serta menuntut betapa pentingnya bagi kita untuk dapat menyiapkan sumber daya manusia yang memadai, mampu beradaptasi dan mampu berkompetisi secara global demi bertahan hidup di masa yang akan datang. Meningkatkan kualitas dari sumber daya manusia melalui pendidikan menjadi salah satu cara untuk dapat menyeimbangkan dengan perkembangan dari revolusi industri 4.0 ini.

Tujuan pendidikan nasional sebagaimana disebutkan dalam Pembukaan UUD 1945 alinea keempat, UU No. 2 Tahun 1985 dan UU No. 20 Tahun 2003 adalah untuk mencerdaskan kehidupan bangsa dan mengembangkan potensi diri sebagai manusia seutuhnya. Pelaksanaan pendidikan dengan bantuan kurikulum menjadi upaya dalam mencapai tujuan tersebut. Namun pendidikan di Indonesia selama 75 tahun belum menunjukkan ketercapaian dari mencerdaskan dan pengembangan potensi rakyatnya. Salah satu penyebabnya adalah upaya pendidikan yang terfokus pada kecerdasan intelektual (IQ/Intelligent Quotient) sehingga pengembangan kecerdasan lain seperti emosional (EI/Emotional Intellegence) dan spiritual (SI/Spiritual Intellegence) sering terlupakan. Ketidaksinambungan supply dunia pendidikan dengan demand dunia industri, keterbatasan akses pendidikan untuk berbagai kalangan, kualitas pendidikan yang rendah dari semua tingkatan dan keterbatasan sumber daya terkualifikasi menjadi beberapa masalah dalam pendidikan Indonesia.

\section{Rumusan Permasalahan}

Upaya peningkatan pendidikan di Indonesia saat ini sudah mulai dilakukan melalui dicanangkannya peningkatan kualitas SDM dalam "Make Indonesia 4.0" oleh Presiden Joko Widodo dan Kemendikbud melalui "Merdeka Belajar" yang mengarah pada otonomi, transparansi, efisiensi dan fleksibilitas pada relevansinya dengan dunia nyata untuk kebutuhan manusia di masa yang akan datang. Perubahan dalam konten, pola dan pendekatan pembelajaran akibat digitalisasi dalam pengembangan kecerdasan intelektual, emosional dan spiritual (bukan hanya kecerdasan intelektual) memunculkan suatu permasalahan dasar secara spasial yaitu perubahan tipologi sekolah atau ruang kegiatan sebagai lingkungan belajar yang fleksibel dan kontinu untuk penggunanya.

\section{Tujuan}

Tujuan penelitian ini adalah untuk mengetahui spasial untuk belajar serta didukung lingkungan belajar yang sesuai dengan perubahan konten, pola dan pendekatan pembelajaran dalam pengembangan kecerdasan untuk kualitas hidup yang lebih baik.

\section{KAJIAN LITERATUR}

\section{Pendidikan di Indonesia}

Pendidikan dapat dikatakan sebagai proses belajar (learning) dan mendapatkan pengetahuan (knowledge). Pendidikan membantu kita untuk dapat mengintepretasikan dan memiliki berbagai pandangan terhadap hal-hal dalam hidup. Pendidikan memiliki peran besar dalam menyiapkan sumber daya manusia yang memadai dan mampu beradaptasi dalam kehidupan. Proses ini menjadi penting bagi diri manusia untuk mengembangkan kemampuan, sikap dan sifat yang penting untuk kehidupan yang sehat, produktif dan bermakna. 
Upaya pencapaian pencerdasan bangsa Indonesia difasilitasi dalam sebuah sistem kurikulum yaitu rancangan atau panduan dalam melaksanakan pembelajaran dan program pendidikan oleh lembaga pendidikan kepada peserta. Kurikulum memiliki peranan penting dalam mengatur dan mengarahkan juga pengawasan dan evaluasi berjalannya sebuah proses pendidikan. Implementasi kurikulum dalam pendidikan di Indonesia mulai berkembang sejak zaman penjajahan Belanda dan Jepang. Perubahan terakhir kurikulum dilakukan pada 2013 dimana kurikulum ini berdasar pada standarisasi kualitas pembelajaran Indonesia di dunia internasional. Prinsip pembelajarannya adalah mengubah pola teacher-centered menjadi student-centered dengan pendekatan ilmiah. Kurikulum ini menekankan pada peningkatan kualitas anak Indonesia untuk dunia kerja di masa yang akan datang, memperkuat kesadaran dan apresiasi terhadap sosial-budaya dan masalah lingkungan di Indonesia dan meningkatkan prestasi anak Indonesia dalam asesmen perbandingan internasional.

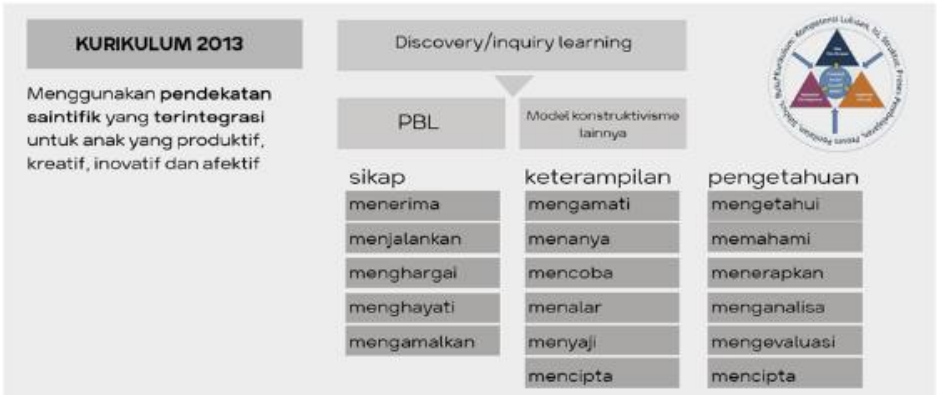

Gambar 1. Konsep dan implementasi Kurikulum 2013 Sumber: Kemendikbud, 2013

\section{Kecerdasan dalam pendidikan}

UNESCO (2014:93) menyebutkan terdapat empat pilar dalam pendidikan sebagai upaya peningkatan mutu pendidikan guna meningkatkan kualitas suatu bangsa, yaitu learning to know, learning to do, learning to be dan learning to live together. Keempat pilar ini menggabungkan tujuan dari IQ (Intelligent Quotient), EQ (saat ini disebut sebagai El/Emotional Intelligence) dan SQ (saat ini disebut sebagai SI/Spiritual Intelligence) yaitu bagian dari yang disebut dengan kecerdasan. Kecerdasan adalah kemampuan seseorang untuk memecahkan masalah yang dihadapi, dalam hal ini adalah masalah yang menuntut kemampuan pikiran serta dapat diukur secara kuantitatif dan kualitatif.

\section{a. Kecerdasan Intelektual/Intelligent Quotient (IQ)}

Kecerdasan intelektual adalah suatu kecerdasan yang digunakan untuk berpikir logis-rasional, yaitu cara berpikir linier yang meliputi proses kognitif seperti kemampuan berhitung, menganalisa sampai mengevaluasi dan seterusnya dalam memahami situasi yang baru. Kecerdasan intelektual hanya menyumbangkan sekitar 4 persen bagi keberhasilan hidup, sedangkan 90 persen keberhasilan ditentukan oleh kecerdasan lainnya

\section{b. Kecerdasan Emosional/Emotional Intelligence (EI)}

Kecerdasan emosional dapat diartikan sebagai kemampuan seseorang untuk mengenali, mengelola perasaan diri sendiri dan orang lain, mampu memotivasi dirinya sehingga membawa kepada keberhasilan. Kecerdasan ini berperan penting dalam proses interaksi manusia dengan lingkungannya, yaitu karakter dalam diri kita sebagai manusia.

\section{c. Kecerdasan Spritual/Spiritual Intelligence (SI)}

Kecerdasan spiritual adalah suatu kecerdasan manusia yang digunakan untuk menyelesaikan permasalahan makna dan nilai, untuk menempatkan perilaku dan hidup dalam konteks makna yang lebih luas sehingga jalan hidupnya lebih bermakna. 
Tujuan pendidikan nasional jelas menyampaikan bahwa pendidikan dilakukan untuk meningkatkan kecerdasan rakyatnya baik itu kecerdasan intelektual, kecerdasan emosional dan kecerdasan spiritual. Namun dalam praktiknya, institusi pendidikan lebih mengarah pada peningkatan kecerdasan IQ, melupakan EI dan SI yang sebenarnya tidak bisa terlepaskan satu dengan yang lainnya.

\section{Konten pembelajaran}

Berkembangnya dunia dalam industrialisasi 4.0 menuntut tidak hanya penguasaan pengetahuan intelektual dan kemampuan bersifat afektif dan psikomotorik. Hal ini terkait dengan kebutuhan dunia yang berubah dengan cepat. Sistem sekolah dasar dan menengah memiliki peran penting dalam mempersiapkan individu global dan mencetak tenaga kerja berkualitas untuk masa mendatang karena perkembangan manusia pada usia muda memiliki dampak positif yang lebih awet dalam seorang individu (WEF, 2020). Konten pendidikan yang sesuai dengan kebutuhan dunia di masa yang akan datang, antara lain adalah global citizenship skill, critical thinking and problem solving, innovation and creativity, technology/digital skill, interpersonal/human-centric dan communication skill.

\section{Pola pembelajaran}

Cara manusia berpikir dan memproses informasi saat ini berbeda dari generasi sebelumnya. Revolusi industri ketiga dan keempat memperkenalkan produksi otomatisasi dan ciptaan dengan nilai yang tidak terwujud. Hal ini memicu perubahan masif dalam kebutuhan keterampilan untuk berkontribusi dalam ekonomi sebagaimana cara orang bekerja. Populasi pelajar saat ini terbiasa dengan akuisisi informasi yang cepat, baik untuk keperluan pendidikan, hiburan atau sosial. Perkembangan teknologi telah mengubah komunitas berbasis pengetahuan menjadi berbasis informasi dan komunikasi.

Perbaruan pola belajar dalam berpikir kritis diperlukan pada semua tingkatan pendidikan guna memfasilitasi kemampuan mereka dalam berkomunikasi, berkolaborasi, refleksi diri dan berkompromi. Perubahan pola pembelajaran menjadi kolaboratif, virtual dan inspiring didasari pada kebutuhan manusia untuk dapat mengembangkan potensi dirinya masing-masing namun dengan beragamnya potensi ini, manusia harus dapat berkolaborasi satu dengan yang lainnya dimana rasa tanggungjawab menjadi tidak hanya pada orang lain, tapi juga pada diri sendiri.

\section{Pendekatan pembelajaran}

Transisi menjadi pendidikan 4.0 juga membutuhkan mekanisme belajar yang dapat merefleksikan sedekat mungkin dengan kebutuhan industri di masa depan. Dengan menekankan student-centered learning, pembelajaran yang dilakukan akan lebih relevan dan terfokus pada anak. Dalam menciptakan ekosistem yang mendukung konten belajar, diperlukan juga prinsip dan strategi belajar mengajar yang sesuai dan inovatif dalam meningkatkan pengalaman belajar (WEF, 2020) antara lain adalah playful, experiential, computational, embodied, multi-literacies dan personalized (self-paced).

Perubahan konten, pola dan pendekatan pembelajaran (pedagogi) menimbulkan permasalahan secara spasial arsitektural sebagai wadah aktivitasnya. Lingkungan fisik dan kualitas sekelilingnya adalah bagian aktif dan tidak terpisahkan dari proses belajar (Taylor, 2009). Arsitektur dapat berperan nyata yaitu keterkaitannya terhadap lingkungan secara fisik. Sehingga dapat ditentukan permasalahan desainnya yaitu bentuk arsitektur pendidikan anak yang dapat mengakomodasi kebutuhan emosional dan akademis anak berdasarkan kecerdasannya. 


\section{METODE PERANCANGAN}

Pengumpulan data untuk proses desain dilakukan secara kualitatif yaitu melalui literatur tulisan, jurnal dan artikel serta observasi. Selanjutnya dilakukan analisis literatur untuk menentukan pendekatan arsitektural dalam sistem pendidikan. Penentuan konsep spasial lingkungan pendidikan yang sesuai dengan kebutuhan akademis, emosional serta spiritual menjadi kunci penting dalam penelitian ini. Melalui pendekatan desain dari teori 8 Multiple Intelligence oleh Howard Gardner (2008) dan Designing Creative Space oleh Katja Thoring maka metode perancangan yang akan digunakan adalah spatial perception yaitu sebuah metode perancangan yang mengarah pada kemampuan melihat, mendengar dan merasakan dalam memahami suatu situasi. Melalui metode perancangan ini sebuah karya arsitektur dapat menjadi target dalam membangun sebuah persepsi emosional dan pengalaman yang juga menjadi bagian dari proses mencapai tujuan perancangan yaitu pengembangan kecerdasan.

\section{DISKUSI DAN HASIL}

Dalam bukunya "Linking Architecture and Education" oleh Anne Taylor (2009), disebutkan beberapa konsep dalam menghubungkan tujuan arsitektur dalam struktur, fungsi dan keindahan dengan tujuan pendidikan dalam pembelajaran secara fisik, kognitif dan emosional. Taylor (2009) menyebutkan dalam mewujudkan pemahaman berbagai ide, teori, pemikiran, kegiatan aktif demi pencapaian kecerdasan dengan relevansi masa depan, sekolah sebagai lingkungan fisik berperan sebagai learning landscape dimana ruangnya secara nyata menjadi alat belajar dengan lingkungan multisensori; sebagai three-dimensional textbook yaitu menggunakan objek fisik sebagai dasar ide atau konsep kemudian berkembang menjadi sesuatu yang abstrak; dan sebagai design studio yaitu kegiatan yang beragam ini diwadahi secara aktif partisipatif.

Pendekatan arsitektural dalam pendidikan dengan sekolah sebagai design studio dinilai paling sesuai dengan penyelesaian terkait salah satu masalah pendidikan di Indonesia dimana IQ>EI dan SI. Lingkungan belajarnya akan terlihat lebih aktif sebagai suatu komunitas karena adanya aktualisasi diri sehingga muncul berbagai interaksi pengalaman yang bervariasi, terbuka dan bermanfaat dalam pembelajaran terapan dan hubungannya dengan dunia nyata. Lingkungan design studio ini didasari dengan metode pendidikan Project/Problem-Based Learning (PBL), yaitu sebuah pendekatan instruksional yang dibangun dari aktivitas pembelajaran dan tugas nyata sebagai konteks yang menantang siswa untuk diselesaikan untuk belajar tentang cara berpikir kritis, keterampilan pemecahan masalah dan memperoleh pengetahuan dan konsep yang esensial dari sebuah tema, topik atau permasalahan (Goodman \& Stivers, 2010).

Proses pembelajaran PBL yang menitikberatkan pada siswa atau student-centered learning membuat siswa didorong untuk mengembangkan pengetahuan, mengekspresikan diri dengan caranya sendiri. Perbedaan dari setiap individu lebih diperhatikan salah satunya adalah dengan mempertimbangkan indikator dan tingkat kecerdasan yang dimiliki oleh setiap anak. Perbedaan ini ditentukan oleh berbagai faktor, antara lain adalah rangsangan yang diberikan pada saat anak masih berusia dini. Teori multiple intelligences oleh Howard Gardner (2008) melihat anak sebagai individu yang unik, bahwa ada banyak variasi dalam belajar yang berakibat pada perbedaan cara pandang dan evaluasinya. Tiap-tiap kecerdasan ini coba diintegrasikan dengan tujuan awal dan masalah pendidikan di Indonesia berkaitan dengan kecerdasan emosionalspiritual. Integrasi antara 8 multiple intelligence dengan tujuannya dalam mencapai kecerdasan emosional-spiritual dideskripsikan sebagai berikut. 
Tabel 1. Kecerdasan emosional-spiritual dalam 8 multiple intelligence

\begin{tabular}{|c|c|}
\hline Multiple Intelligence & Tujuan Kecerdasan Emosional-Spiritual \\
\hline Verbal-Linguistik & $\begin{array}{l}\text { Kemampuan dalam menggunakan bahasa untuk menjelaskan sesuatu, } \\
\text { berargumen, membangun kepercayaan dan hubungan }\end{array}$ \\
\hline Logis-Matematis & $\begin{array}{l}\text { Kemampuan dalam menggunakan konsep matematika (logis) untuk } \\
\text { membuat dugaan, menggunakan data, memberi bukti dalam berargumen }\end{array}$ \\
\hline Visual-Spasial & $\begin{array}{l}\text { Kemampuan dalam berimajinasi, menginterpretasi dan secara grafis } \\
\text { merepresentasikan ide visual untuk inovasi dan pemecahan masalah }\end{array}$ \\
\hline Kinestetik & $\begin{array}{l}\text { Kemampuan dalam menggunakan tubuh untuk melakukan aksi yang } \\
\text { efektif, membangun hubungan dan mengekspresikan diri }\end{array}$ \\
\hline Musikal & $\begin{array}{c}\text { Kemampuan untuk merespon secara emosional, mengintepretasikan } \\
\text { sebuah ide kreatif untuk pemenuhan kebutuhan }\end{array}$ \\
\hline Interpersonal & $\begin{array}{c}\text { Kemampuan dalam mengorganisir, menginspirasi dan } \\
\text { membantu sesama dalam menyelesaikan masalah }\end{array}$ \\
\hline Intrapersonal & $\begin{array}{c}\text { Kemampuan dalam memahami diri sendiri untuk } \\
\text { mengekspresikan diri dan untuk kepentingan sesama }\end{array}$ \\
\hline Naturalis & $\begin{array}{l}\text { Kemampuan dalam menggunakan lingkungan alam untuk } \\
\text { membangun kesadaran akan peran aktif dalam komunitas global }\end{array}$ \\
\hline
\end{tabular}

Sumber: Dokumentasi Pribadi, 2020

Dalam menentukan konsep spasial berdasarkan multiple intelligence dalam mencapai kecerdasan emosional-spiritual penulis menggunakan "Designing Creative Space" oleh Katja Thoring (2019) sebagai dasar melalui uraian dari physical pattern dan spatial quality-nya. Pola desain ini dipilih yang paling sesuai antara deskripsi dengan kegiatan dan tujuan pembelajarannya, sehingga memunculkan kriteria spatial quality dan bentuk tipe dari ruangnya untuk membantu proses perancangan.

Tabel 2. Kriteria desain ruang berdasarkan 8 multiple intelligence

\begin{tabular}{|c|c|c|}
\hline LEARNING GOALS & LEARNING ACTIVITY & PHYSICAL PATTERN \& SPATIAL QUALITIES \\
\hline \multirow[t]{2}{*}{$\begin{array}{l}\text { Verbal/ } \\
\text { Linguistik }\end{array}$} & \multirow{2}{*}{$\begin{array}{l}\text { Menulis } \\
\text { cerita/artikel, } \\
\text { mendengarkan } \\
\text { cerita, membaca, } \\
\text { bercerita, debat, } \\
\text { words puzzle } \\
\text { (scrabble, } \\
\text { crosswords) }\end{array}$} & $\begin{array}{l}\text { Fleksibel, santai, luas, aktif, terbuka, stair seating, } \\
\text { circle sitting, gathering space, perabot movable dan } \\
\text { foldable untuk kemudahan penyusunan kembali, } \\
\text { punya variasi tempat dan ketinggian duduk sehinga } \\
\text { ada ragam postur kerja dengan penglihatan yang lebih } \\
\text { baik dan partisipan yang lebih aktif, writable surface, } \\
\text { ketersediaan alat-alat - collaboration, making } \\
\text { presentation dan intermission }\end{array}$ \\
\hline & & $\begin{array}{l}\text { - process enabler (fleksibel, tetap, behavior, alur } \\
\text { kerja) } \\
\text { - knowledge processor (aksesibilitas, visibel) }\end{array}$ \\
\hline \multirow[t]{2}{*}{$\begin{array}{l}\text { Logika/ } \\
\text { Matematik }\end{array}$} & \multirow{2}{*}{$\begin{array}{l}\text { Bereksperimen, } \\
\text { membuat kode-kode, } \\
\text { membuat analogi, } \\
\text { mencari dan } \\
\text { menganalisa pola, } \\
\text { mengorganisir data, } \\
\text { klasifikasi, } \\
\text { penjumlahan, } \\
\text { pengurangan, math } \\
\text { puzzle (domino, } \\
\text { catur, Monopoly) }\end{array}$} & $\begin{array}{l}\text { Tetap, adaptable, memiliki tempat penyimpanan } \\
\text { terbuka, dinding display, area kerja bersama, kegiatan } \\
\text { interaktif dengan lingkungan, memilki area untuk } \\
\text { mengumpulkan ide sendiri dalam sebuah moodboard, } \\
\text { perabot movable dan foldable, ketersediaan alat-alat - } \\
\text { collaboration dan making }\end{array}$ \\
\hline & & $\begin{array}{l}\text { - process enabler (fleksibel, tetap, behavior, alur } \\
\text { kerja) } \\
\text { - stimulation (inspirasi, distraksi, kejutan, gangguan) } \\
\text { - knowledge processor (aksesibilitas, visibel) }\end{array}$ \\
\hline
\end{tabular}




\begin{tabular}{|c|c|c|}
\hline \multirow[t]{2}{*}{$\begin{array}{l}\text { Visual/ } \\
\text { Spasial }\end{array}$} & \multirow{2}{*}{$\begin{array}{l}\text { Mengambil dan } \\
\text { merekam gambar, } \\
\text { mind-mapping, } \\
\text { membuat ilustrasi, } \\
\text { mengerjakan proyek } \\
\text { 3D (bermain dengan } \\
\text { tanah liat, lilin dan } \\
\text { sejenisnya), } \\
\text { menggambar, } \\
\text { bermain jigsaw } \\
\text { puzzle, memory } \\
\text { games }\end{array}$} & $\begin{array}{l}\text { Teratur, menggunakan tangan, personal workspace, } \\
\text { project work area, tempat penyimpanan terbuka, } \\
\text { menggunakan lantai asimetris dalam menciptakan } \\
\text { ruang dengan perspektif yang menarik dan nyaman, } \\
\text { stimulasi oleh beragam cahaya dalam memberikan } \\
\text { suasana yang berbeda-beda, memiliki koleksi material, } \\
\text { teknik atau alat yang dapat menjadi inspirasi - } \\
\text { collaboration dan making }\end{array}$ \\
\hline & & $\begin{array}{l}\text { - process enabler (fleksibel, tetap, behavior, alur } \\
\text { kerja) } \\
\text { - stimulation (inspirasi, distraksi, kejutan, gangguan) } \\
\text { - knowledge processor (aksesibilitas, visibel) }\end{array}$ \\
\hline \multirow[t]{2}{*}{$\begin{array}{l}\text { Bodily/ } \\
\text { Kinestetik }\end{array}$} & \multirow{2}{*}{$\begin{array}{l}\text { Simulasi/role play, } \\
\text { membuat/merakit } \\
\text { sesuatu, permainan } \\
\text { interaktif, bermain } \\
\text { sejenis hide and seek, } \\
\text { membangun, } \\
\text { sequencing, } \\
\text { discovering }\end{array}$} & $\begin{array}{l}\text { Aktif, platform pertunjukan, ruang observasi, area } \\
\text { bermain dengan permainan, alat dan fasilitas untuk } \\
\text { mendukung eksperimen dan aktivitas, area kerja } \\
\text { bersama, area kerja personal, memiliki koleksi } \\
\text { material, teknik atau alat yang dapat menjadi inspirasi } \\
\text { - collaboration, presentation intermission dan making }\end{array}$ \\
\hline & & $\begin{array}{l}\text { - stimulation (inspirasi, distraksi, kejutan, gangguan) } \\
\text { - knowledge processor (aksesibilitas, visibel) }\end{array}$ \\
\hline \multirow[t]{2}{*}{$\begin{array}{l}\text { Musikal/ } \\
\text { Ritme }\end{array}$} & \multirow{2}{*}{$\begin{array}{l}\text { Mengenal macam- } \\
\text { macam bunyi, } \\
\text { mendengarkan } \\
\text { musik, membuat lagu } \\
\text { dari sebuah ide/teks, } \\
\text { mengenal macam- } \\
\text { macam musik, } \\
\text { mendengarkan } \\
\text { cerita, melakukan } \\
\text { podcast }\end{array}$} & $\begin{array}{l}\text { Ambient background noise membuat beberapa orang } \\
\text { aktif dan kreatif, dengan perabot movable dan } \\
\text { foldable untuk kemudahan penyusunan kembali, area } \\
\text { bermain dengan permainan, alat dan fasilitas untuk } \\
\text { mendukung eksperimen dan aktivitas - collaboration } \\
\text { dan intermission }\end{array}$ \\
\hline & & $\begin{array}{l}\text { - process enabler (fleksibel, tetap, behavior, alur } \\
\text { kerja) } \\
\text { - stimulation (inspirasi, distraksi, kejutan, gangguan) }\end{array}$ \\
\hline \multirow[t]{2}{*}{ Interpersonal } & \multirow{2}{*}{$\begin{array}{l}\text { Bekerja dan bermain } \\
\text { dalam kelompok/ } \\
\text { berpasangan, } \\
\text { mentoring, berdebat }\end{array}$} & $\begin{array}{l}\text { Susuan kelompok dari area duduk untuk mengundang } \\
\text { pertemuan santai, ruang untuk pertemuan atau } \\
\text { studio untuk berbagai kebutuhan yang lebih personal, } \\
\text { handmade appereance and dan material mentah } \\
\text { untuk membangun suasana eksperimental, area kerja } \\
\text { komunal, area duduk (bean bag) untuk relaksasi dan } \\
\text { pekerjaan santai - intermission dan collaboration }\end{array}$ \\
\hline & & $\begin{array}{l}\text { - process enabler (fleksibel, tetap, behavior, alur } \\
\text { kerja) } \\
\text { - stimulation (inspirasi, distraksi, kejutan, gangguan) } \\
\text { - social dimension (ketidaksengajaan, pemisahan) } \\
\text { - culture (aturan, ritual, tanggungjawab, hak, } \\
\text { toleransi) }\end{array}$ \\
\hline \multirow[t]{2}{*}{ Intrapersonal } & \multirow{2}{*}{$\begin{array}{l}\text { Membuat } \\
\text { autobiografi, } \\
\text { scrapbook, jurnaling, } \\
\text { self-reflect, bercerita }\end{array}$} & $\begin{array}{l}\text { Ruang semi-privat yang transparan (misalnya dengan } \\
\text { dinding kaca), perpustakaan informal dengan area } \\
\text { santai yang menyediakan buku sebagai faslitias riset, } \\
\text { stop kontak, info digital, bekerja dimana saja, area } \\
\text { kerja komunal, area duduk (bean bag) untuk relaksasi } \\
\text { dan pekerjaan santai - collaboration dan intermission }\end{array}$ \\
\hline & & $\begin{array}{l}\text { - process enabler (fleksibel, tetap, behavior, alur } \\
\text { kerja) } \\
\text { - knowledge processor (aksesibilitas, visibel) } \\
\text { - stimulation (inspirasi, distraksi, kejutan, gangguan) } \\
\text { - social dimension (ketidaksengajaan, pemisahan) } \\
\text { - culture (aturan, ritual, tanggungjawab, hak, } \\
\text { toleransi) }\end{array}$ \\
\hline
\end{tabular}




\begin{tabular}{|c|c|c|}
\hline \multirow[t]{2}{*}{ Naturalis } & \multirow{2}{*}{$\begin{array}{l}\text { Merawat tanaman, } \\
\text { pengamatan } \\
\text { lingkungan alam } \\
\text { (binatang dan } \\
\text { tumbuhan), meneliti } \\
\text { masalah lingkungan }\end{array}$} & $\begin{array}{l}\text { Area hijau dengan tanaman yang dibudidayakan } \\
\text { sendiri untuk dapat dirawat dan diamati sebagai } \\
\text { bentuk tanggung jawab dan empati anak- } \\
\text { intermission, making }\end{array}$ \\
\hline & & - stimulation (inspirasi, distraksi, kejutan, gangguan) \\
\hline
\end{tabular}

Sumber: Rangkuman dari Gardner (2008) dan Thoring (2019)

Berdasarkan hasil analisis literatur kemudian dilakukan analisis kreatif dalam memvisualisasikan lingkungan belajar yang dapat memenuhi kebutuhan secara nyata dalam bentuk arsitektural. Bangunan arsitektural berbentuk sekolah menjadi tempat yang paling umum dan formal dimana sebuah proses pendidikan di lakukan. Sekolah juga menjadi platform kesempatan semua anak mendapatkan haknya dalam pendidikan. Mengingat sebagian besar waktu pelajar dihabiskan di sekolah (bahkan dapat dikatakan sebagai rumah kedua) sisi arsitektural bangunannya menjadi penting karena dapat mempengaruhi seberapa baik kualitas belajar mereka.

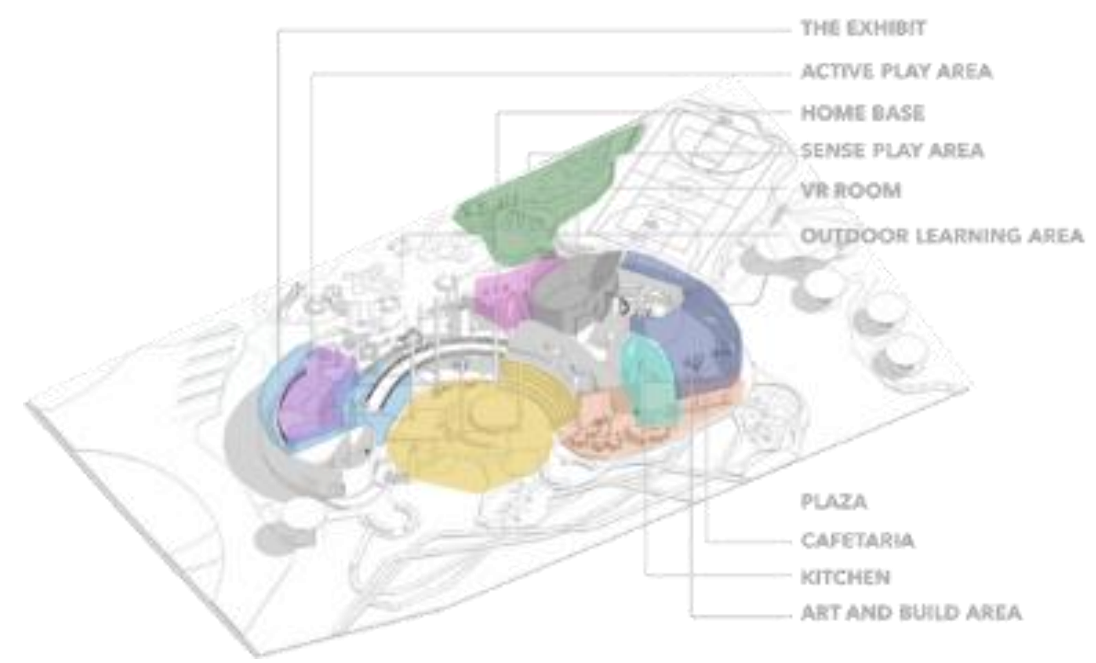

Gambar 2. Implementasi prinsip belajar pada bangunan Sumber: Penulis, 2020

"Ruang kelas" berubah dari yang terkelompok dalam sebuah ruangan secara formal menjadi menyebar dengan suasana yang lebih informal karena pembelajarannya mengarah pada peserta didik. Areanya beragam dan fleksibel dengan susunan perabot fleksibel yang dapat digunakan untuk area kerja individu juga area diskusi dan area presentasi. Three side table digunakan sebagai perabot yang mungkin tidak efektif untuk kerja individu namun sesuai dengan prinsip belajar kolaboratif-partispatif, bentuk ini akan menjadi lebih fungsional saat digabungkan seakan-akan "memaksa" anak untuk bekerja secara kolaboratif. Meja dengan bentuk seperti ini juga memiliki banyak susunan untuk digunakan dalam skala kecil maupun besar.
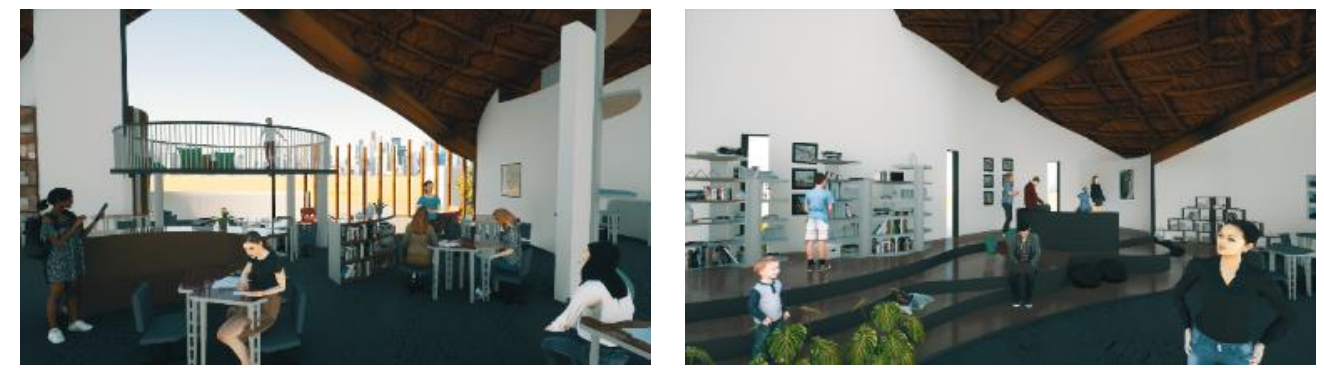

Gambar 3. Ruang informal yang terbentuk dari sistem pembelajaran student-centered Sumber: Penulis, 2020 
Dalam proses PBL, pembelajaran berdasarkan pengalaman (experiential learning) menjadi salah satu fokus karena prosesnya yang efektif dimana keterlibatan emosional dalam proses belajar ini lebih besar. Area yang menyediakan beragam pengalaman ruang dengan berbagai kegiatan akan lebih berdampak daripada sebuah ruang kosong dengan meja dan kursi saja. Penggunaan kelima indra dalam sebuah kegiatan pembelajaran juga akan menambah efek experiential. Namun karena berbagai keterbatasan tidak semua pengalaman ini bisa dipenuhi dalam sebuah ruang/arsitektur. Teknologi seperti Virtual Reality (VR) dapat digunakan untuk memenuhi keterbatasan tersebut.
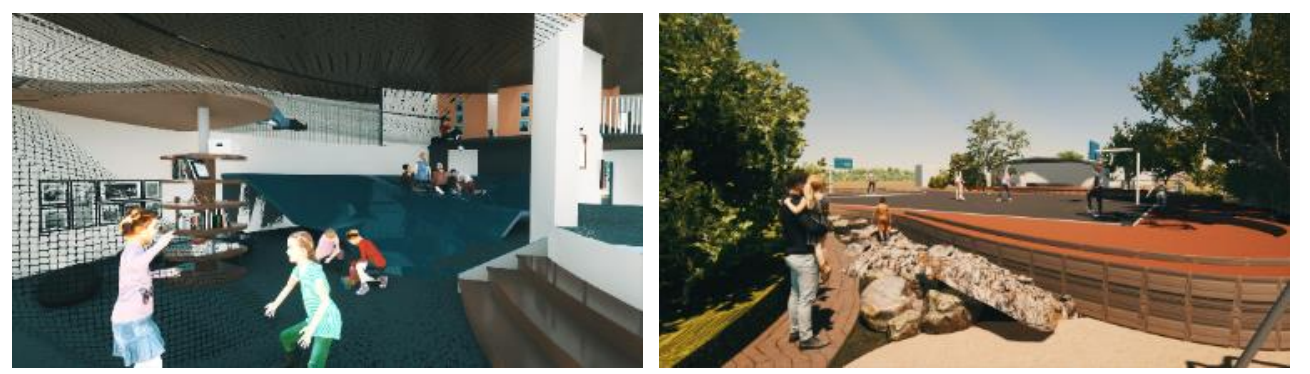

Gambar 4. Bermain jaring, memanjat merangkak, merasa sebagai bentuk dari experiential learning

Sumber: Penulis, 2020

Experiential learning juga dapat dilakukan melalui kegiatan seperti role play, dimana anak bisa lebih memahami dan merasakan langsung perspektif dari suatu dasar pemikiran. Salah satu contohnya adalah melalui adanya kantin anak dimana anak-anak yang mengelolanya secara mandiri. Hal ini bertujuan untuk melatih kemampuan berbicara, mengorganisir serta penerapan ekonomi dasar.

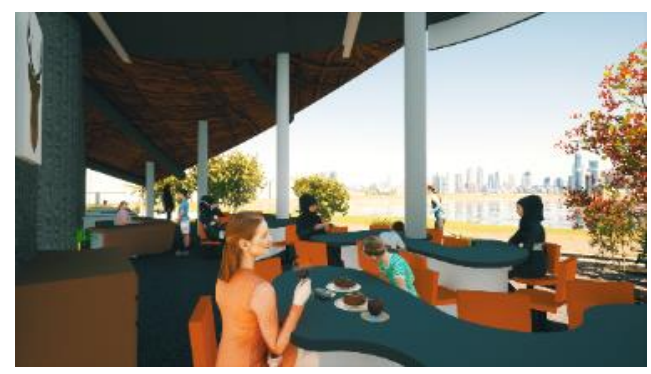

Gambar 5. Makan dan belajar bersama pada jam istirahat Sumber: Penulis, 2020

Wadah presentasi ekspresi diri juga diperlukan sebagai bagian dari proses belajar dalam PBL yaitu penyajian hasil karya/belajar dalam sebuah asesmen. Lingkungan belajar ini dapat berupa area pameran hasil karya anak, yang berguna untuk memotivasi anak, melatih rasa percaya diri serta melatih kecerdasan linguistiknya (dalam menjelaskan sesuatu).

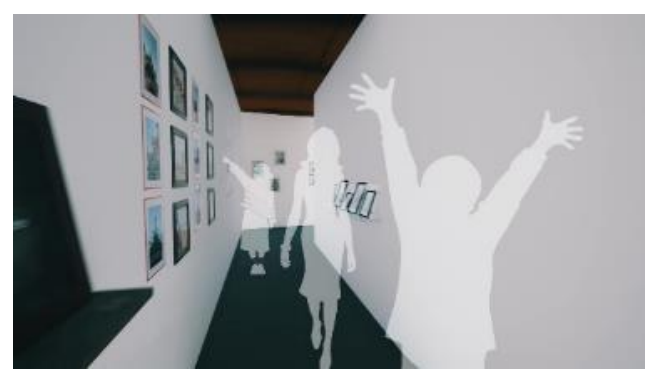

Gambar 6. Pameran hasil kerja anak kepada publik melalui sebuah ruang arsitektur Sumber: Penulis, 2020 
Ruang dimana anak dapat berkreatifitas membangun dan membentuk sesuatu dengan alat-alat bantu kerja yang tersedia dan mudah diakses dapat mewadahi penggekspresian ide kreatif dan pengembangan kecerdasan secara visual-spasial. Ruang seperti ini dapat menjadi lingkungan yang produktif bagi peserta didik untuk dapat bekerja dengan nyaman tanpa terlalu mengganggu kelompok belajar metode lainnya.

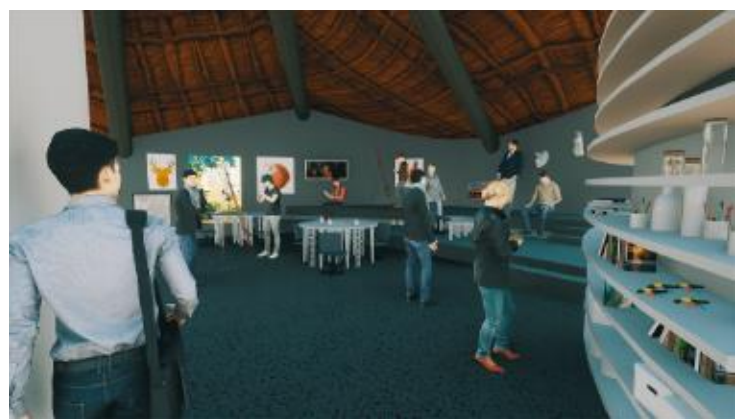

Gambar 7. Ruang untuk pengembangan kecerdasan visual-spasial Sumber: Penulis, 2020

Area dengan panggung juga dapat menjadi lingkungan pendukung untuk pengembangan diri dalam mengekspresikan diri baik secara verbal, kinestetik, logis ataupun musikal. Area ini juga dapat menjadi area berkumpul untuk kelompok besar yang kegiatannya lebih formal seperti seminar, pertunjukkan, dsb atau digunakan sehari-hari sebagai area bermain anak yang ramai saat jam istirahat atau tempat untuk mengerjakan tugas.

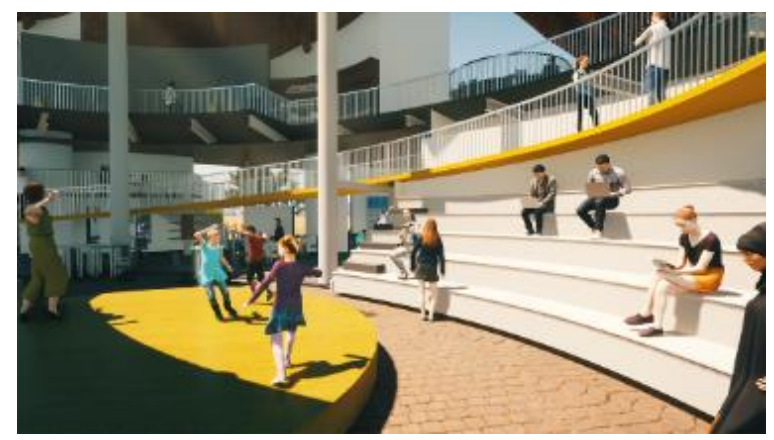

Gambar 8. Plaza tempat anak berkegiatan bersama beramai-ramai Sumber: Penulis, 2020

Elemen spasial lain yang dapat digunakan untuk ekspresi diri antara lain adalah dinding. Pada dinding ini anak bisa menyampaikan ide kreatifitasnya dengan tujuan melatih keberanian untuk tampil, mengekspresikan diri, berani dikritik. Proses perekaman juga dilakukan sebagai bentuk dokumentasi dan bukti bahkan dapat digunakan sebagai salah satu alat penilaian informal anak.

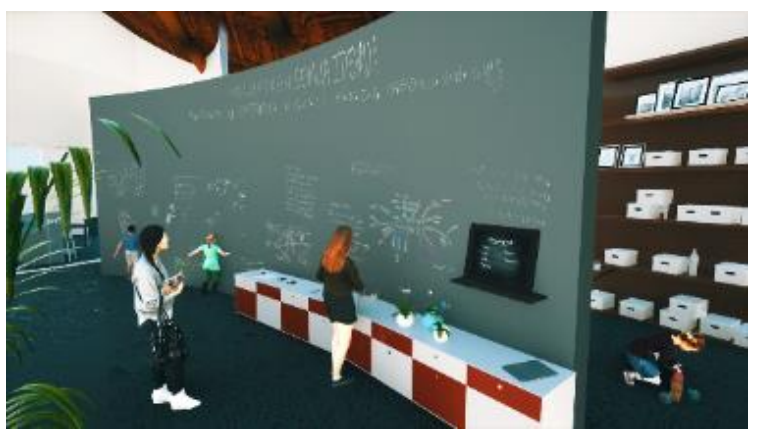

Gambar 9. Dinding dimana anak dapat menggambarkan ide ekspresi dirinya Sumber: Penulis, 2020 


\section{KESIMPULAN DAN SARAN}

\section{Kesimpulan}

Perubahan dalam konten, pola dan pendekatan pembelajaran akibat digitalisasi dalam pengembangan kecerdasan intelektual, emosional dan spiritual (bukan hanya kecerdasan intelektual) telah mengubah ruang kegiatan sebagai lingkungan belajar. Lingkungan ini tidak hanya sebagai wadah namun juga sebagai bagian dari proses pembelajaran yang harus dapat mewujudkan pemahaman berbagai ide, teori, pemikiran, kegiatan aktif demi pencapaian kecerdasan dengan relevansi masa depan. Salah satunya adalah melalui sekolah yang berperan sebagai design studio sehingga lingkungan belajarnya akan terlihat lebih aktif sebagai suatu komunitas karena adanya aktualisasi diri. Melalui metode PBL, proses pembelajaran menjadi student-centered sehingga perbedaan dari setiap individu lebih diperhatikan. Tiap kecerdasan dalam teori multiple intelligences ini dicoba diintegrasikan dengan tujuan awal dan masalah pendidikan di Indonesia berkaitan dengan kecerdasan emosional-spiritual dan ditentukan kegiatan pembelajaran serta kriteria desain ruangnya.

Beberapa perwujudan perubahan lingkungan belajar sekolah antara lain adalah dengan berubahnya "ruang kelas" menjadi menyebar di seluruh sekolah dengan suasana yang lebih fleksibel dan informal, didukung dengan perabot yang fleksibel pula. Lingkungan yang mendukung experiential learning juga menjadi fokus perubahan yaitu area dengan beragam pengalaman ruang dan kegiatan dimana anak menggunakan tubuhnya untuk belajar. Penyediaan ruang untuk kegiatan yang lebih nyata seperti kantin anak serta penggunaan teknologi VR juga dapat menjadi bagian dari proses pembelajaran. Lingkungan belajar juga harus dapat mendukung ekspresi diri anak untuk pengembangan kecerdasan emosionalnya, antara lain melalui adanya ruang pameran hasil karya, ruang seni dan bangun, area panggung bahkan elemen dinding yang dapat dicoret.

Melalui perwujudan perubahan lingkungan belajar menjadi lebih fleksibel dan kontinu ini diharapkan proses pembelajaran dapat berjalan sesuai dengan perubahan kebutuhan dunia dalam mencapai kecerdasan anak demi pengembangan diri untuk kualitas hidup yang lebih baik.

\section{REFERENSI}

Gardner, H. (2008). Multiple Intelligences: The Theory in Practice a Reader. New York: Basic Books.

Goleman, D. (1996). Emotional Intelligence: Mengapa El lebih penting daripada IQ. (terj. Hermaya) Jakarta: Gramedia.

Goodman, B., \& Stivers, J. (2010). Project-Based Learning. Educational Psychology (ESPY) 505. Diakses melalui http://www.fsmilitary.org/pdf/Project_Based_Learning

Kementerian PPN/Bappenas. (2017). Bonus Demografi 2030-2040: Strategi Indonesia terkait Ketenagakerjaan dan Pendidikan. Jakarta: Siaran Pers Kementerian PPN/Bappenas.

Kominfo. (2020, Januari 28). Revolusi Industri 4.0. Diakses melalui Kementerian Komunikasi dan Informatika RI: https://aptika.kominfo.go.id/2020/ 01/revolusi-industri-4-0/

Makarim, N. (2020, Mei 6). Konferensi Pendidikan Akademi Edukreator [Video]. Kok Bisa? [YouTube channel]. Diakses melalui https://youtu.be/L-9HTAowX3Y

National Institute of Education (NIE) Singapore. (2017). Presentation to ICSEI on Singapore's Education System. Singapore.

Norberg-Schulz, C. (1985). The Concept of Dwelling: on the way to figurative architecture. New York : Rizzoli

Pasiaq, T. (2016). Manajemen Kecerdasan: Memberdayakan IQ, EQ, dan SQ untuk Kesuksesan Hidup. Bandung: Mizan. 
Programme for International Student Assesstment (PISA). (2018). PISA 2018 results. Diakses melalui OECD: https://www.oecd.org/pisa/publications/pisa-2018-results.htm

Satu Banten. (2020, Februari 20). Catatan Pembangunan Pendidikan Di Banten. Satu Banten. Diakses melalui https://satubanten.com/catatan-pembanguanan-pendidikan-di-banten/

Schwab, K. (2016, Januari 14). The Fourth Industrial Revolution: What It Means, How to Respond. Diakses melalui World Economic Forum: https://www.weforum.org/agenda/2016/01/the-fourth-industrial-revolution-what-itmeans-and-how-to-respond

Sennett, R. (2018). Building and Dwelling: Ethics for the City. London: Penguin Books.

Taylor, A. P. (2009). Linking architecture and education: sustainable design for learning environments. Albuquerque: University of New Mexico Press.

The World Bank IBRD-IDA. (2018). Indonesia Economic Quarterly: Learning more, growing faster. The World Bank.

Thoring, Katja (2019). Designing Creative Space: A Systemic View on Workspace Design and its Impact on the Creative Process. Diakses melalui https://doi.org/10.4233/uuid:77070b579493-4aa6-a9a5-7fed52e45973

Vartanian, O., dkk (2013, Juni 18). Impact of contour on aesthetic judgments andapproachavoidance decisions in architecture. PNAS, 110, 10446-10453.

World Economic Forum. (2020). Schools of the Future: Defining New Models of Education for the Fourth Industrial Revolution. Switzerland: World Economic Forum. 